\title{
Short-term circular migration and gendered negotiation of the right to the city: The case of migrant live-in care workers in Basel, Switzerland
}

Chau, Huey Shy ; Pelzelmayer, Katharina ; Schwiter, Karin

DOI: https://doi.org/10.1016/j.cities.2017.04.004

Posted at the Zurich Open Repository and Archive, University of Zurich ZORA URL: https://doi.org/10.5167/uzh-142127

Journal Article

Accepted Version

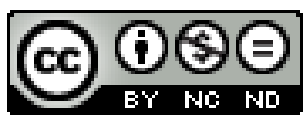

The following work is licensed under a Creative Commons: Attribution-NonCommercial-NoDerivatives 4.0 International (CC BY-NC-ND 4.0) License.

Originally published at:

Chau, Huey Shy; Pelzelmayer, Katharina; Schwiter, Karin (2018). Short-term circular migration and gendered negotiation of the right to the city: The case of migrant live-in care workers in Basel, Switzerland. Cities, 76:4-11.

DOI: https://doi.org/10.1016/j.cities.2017.04.004 
Chau, Huey Shy / Pelzelmayer, Katharina / Schwiter, Karin 2017:

Short-term circular migration and gendered negotiation of the right to the city:

The case of migrant live-in care workers in Basel, Switzerland ${ }^{1}$

in: Cities. The international journal of urban policy and planning. Online first.

\begin{abstract}
This article focuses on live-in elder care workers in German-speaking Switzerland, with a focus on the city of Basel. Working with the Lefebvrian concept of le droit à la ville, it critically investigates the extent to which circularly migrating women can negotiate their right to the city when working as private 24-hour carers in Basel. It first discusses how the Swiss migration and labor regimes in this gendered field of work affect their rights, access, belonging, and participation in the city. The article then analyzes two examples of how live-in care workers challenge existing regulations individually and collectively, and instigate changes at the level of the city. Exploring the idea of participation beyond formal recognition such as residency and citizenship, the paper critically reflects on the right-to-the-city debate's key concept of inhabitance. Focusing on women who - as circular migrants - only reside in Switzerland for a few weeks at a time and who - as live-in workers - are often isolated in private households, the paper argues that work arrangements and mobility are key to understanding inhabitants' right to the city.
\end{abstract}

\title{
KEYWORDS
}

labor migration, working conditions, right to the city, gender, care work, Basel

\section{INTRODUCTION}

In the last few years, an increasing number of private agencies have been offering 24-hour care to the Swiss elderly in their private homes. They employ or place women from EU countries in Swiss households for two to twelve weeks at a time. For some workers, this is only a one-time temporary deployment. In the majority of cases, however, the women regularly commute between their 'home' and 'work' countries. (Schilliger 2014; Schwiter, Berndt and Truong 2015). The literature discusses this specific mobility pattern in which workers go back and forth on a regular basis as 'circular migration' (Mansoor and Quillin 2007; Triandafyllidou and Marchetti 2013; Vertovec 2007).

\footnotetext{
${ }^{1}$ All authors with equal contribution. The research for this paper has been funded by the Swiss National Science Foundation and by the University of Zurich.
} 
While the care workers are in Switzerland, they live in the seniors' private households. Even though they are de facto residents in Switzerland for this period of time, they are often described in a narrative that firmly locates them in their 'home' countries and not in the places where they work and live as 24-hour care workers (Pelzelmayer and Schwiter 2015). This discursive placement is reflected in their residence status, working conditions, legal protection - and participation in everyday local community life.

As existing research has shown, both traditional guest worker programs and more recent temporary migration schemes often restrict the rights of migrant workers (Castles 2006; Plewa and Miller 2005; Ruhs and Martin 2008; Wickramasekara 2008). They might for instance limit the duration of stay, prohibit family reunion, infringe the freedom to change employer and impede access to unemployment and other social security benefits (Bakan \& Stasiulis 2012). Furthermore, the often temporary nature of labor migration is an obstacle to traditional ways of organizing workers (Piper 2010).

For domestic workers from other countries, migration law interlinks with labor law, which in many countries does not provide full protection if the private household is the workplace (ILO 2013). Consequently, migrant domestic workers - and live-in workers in particular - often face what Fudge $(2011,235)$ has termed a "conundrum of jurisdiction" that exposes them to exploitation. In the case of circular migration, with workers alternating between their 'work' and 'home' countries, this means that 'they end up not being a fullcitizen [neither] here nor there" (Marchetti 2015, 75).

The present article analyzes live-in care workers' position in German-speaking Switzerland, with a specific focus on Basel. Acknowledging the importance of work-related issues in urban politics, the paper refers to Henri Lefebvre's concept of the right to the city (Lefebvre 1968). It does so with a view to exploring the potential to address questions related to the four aspects of rights, access, belonging, and participation in a situation of heightened mobility. Since issues of gender and country/place of origin are highly relevant in 24-hour care, the paper works with gendered readings of the right-to-the-city debate. Accordingly this paper addresses the following questions: Given their circular migration status, their temporary work arrangements, and the fusion of workplace and residence, what are the difficulties that live-in care workers face to claim their 'right to the city'? How do care workers negotiate this right in Basel? How do they participate in everyday life in the city?

In the following sections, we first discuss how we read Lefebvre's right to the city through a gender lens. After a brief presentation of the material and methods, the results 
section explores the situation of circularly migrating 24-hour caregivers in German-speaking Switzerland. We investigate the ways in which the specific nexus of migration and labor regimes affects their rights, access, belonging, and participation in the city. We focus on Basel to discuss two cases in which care workers challenge the existing regimes at an individual as well as at a collective level. In our conclusions, we reflect on what our foregrounding of work arrangements and circularly migrating inhabitants might add to the right-to-the-city debate.

\section{THEORETICAL FRAMEWORK}

\subsection{Lefebvre's le droit à la ville: collectivist politics, inhabitance, and the gender lens}

In Le droit à la ville, Henri Lefebvre (1968) rejected the formalities of participation on the level of the nation-state. Urban space was to become the locus for decision-making. Lefebvre's idea of a right to the city addresses issues of legal rights, access to resources, belonging, and participation (Kofman and Lebas 1996; Purcell 2003). It demands that all inhabitants of a city have a right to the social, economic and cultural resources in the city and it calls not just for a reform, but for a radical restructuring of social, political and economic relations in the city and beyond (Butler 2012). All inhabitants of a city should be able to participate in decision making and have the right to appropriate the city as their own. It thus underlines the need for a fundamental shift in the power relations that underlie the production of urban space, so that control is transferred from the state and capital and to urban inhabitants (Purcell 2002).

Today, there is not only considerable interest in the (global) city (Domosh and Seager 2001, 67; Joy and Vogel 2015; Sassen 2001) and (access to) rights, but also in the concept of the right to the city, particularly because "political and economic restructuring in cities is negatively affecting the enfranchisement of urban residents" (Purcell 2002, 99). Research drawing on the debate has focused for instance on (public) housing (Fenton et al. 2013), on social media and activism (Tayebi 2013), and on (minority) group participation and rights (Jabareen 2014). As such, activist groups have also adopted the concept (Mullis 2014). For example, the World Social Forum $(2004,2)$, an open grassroots platform that brings together a large number of civil society groups, developed a World Charter for the Right to the City, which reads, 
"1. All persons have the Right to the City free of discrimination based on gender, age, health status, income, nationality, ethnicity, migratory condition, or political, religious or sexual orientation (...).",

Often the concept is employed to support individuals in claiming their rights. From a gender perspective, however, scholars have questioned this interpretation of Lefebvre's ideas and the liberal framework in which such universal rights-based claims are often articulated (Brown 2000). Feminist and critical scholars working with the right-to-the-city go beyond a rights-based language and emphasize Lefebvre's vision of collective forms of participation and inhabitance.

First, Harvey $(2012,3)$ for example recognizes the potential of the right to the city as not just an issue of individualized rights and access. He foregrounds its possibilities of collectivistic participation:

"The right to the city is far more than the individual liberty to access urban resources: it is a right to change ourselves by changing the city. It is, moreover, a common rather than an individual right since this transformation inevitably depends upon the exercise of a collective power to reshape the processes of urbanization. The freedom to make and remake our cities and ourselves." (Harvey 2008, 23)

The right to the city as participation and appropriation therefore also encompasses the right to reshape and transform the city collectively, and the right to form alliances in order to change existing norms, rules, and regulations.

Second, gendered readings of Lefebvre foreground his concept of inhabitance as the basis for (local, urban) participation. Fenster $(2005,218-219)$ for example explains that 'Lefebvre doesn't define belonging to a political community in the terminology of formal citizenship status, but bases the right to the city on inhabitance", and Purcell $(2002,99)$ talks about an "urban politics of the inhabitant". So while conventional enfranchisement addresses only national citizens, the right to the city speaks of inhabitants, urban dwellers, or what Lefebvre (1991) calls citadins - a term that combines the notion of citizen with inhabitant and denizen. In addition, Lefebvre uses the French word habiter, which refers not only to dwelling but also to a way of living that involves appropriating the city as one's own (see Kofman and Lebas 1996, pp. 17).

Inhabitance thus speaks to 'lived space' and people's 'actual' experience of a given space (Lefebvre 1991). Central here are people's everyday rhythms of life (Lefebvre 1992). A Lefebvrian analysis of these rhythms opens up the possibility that - instead of nationality, 
ethnicity, or birth - one's own experiences of everyday life in the city is the basis for participation (Purcell 2002). A focus on people's experiences of every day life also gives room and potential to new forms of contestation, in which people begin to manage urban space by themselves and for themselves (Butler 2012, 104).

Fenster (2005) discusses these everyday experiences as creating multi-layered forms of belonging. Inhabitance as the basis of belonging and participation in everyday life is a tempting proposition. However, what does inhabitance mean beyond formal recognition such as residency and citizenship, particularly in a context of mobility (Nagel and Staeheli 2004)? How do circular migrants participate as inhabitants while being present only intermittently? To what extent can they be citadins in more than one city at once? Lefebvre argues that the bourgeois aristocracy that moves from grand hotel to grand hotel can no longer be considered inhabitants (Lefebvre 1996, 159). But what about workers who might be equally mobile but for entirely different reasons? The case of migrant live-in care workers in Basel offers a unique opportunity to explore these intricate questions. In the following, the article outlines how a critical reading of the right-to-the-city framework can support a gendered analysis of a contemporary multi-local phenomenon such as 24-hour care.

\subsection{4-hour care in Switzerland and the right to the city}

The article builds on two points addressed in the right-to-the-city debate. First, 24-hour care seldom takes place in what is understood as 'public' space (Schilliger 2013). Care workers are therefore often poorly visible in the 'public' sphere. Second, the right to the city does not necessarily relate to the 'private' sphere of the household (Fenster 2005; Staeheli and Dowler 2002). While gendered perspectives have applied the concept to (certain groups of) women's negotiation of public space (Hackenbroch 2013) and to housing (Fenton et al. 2013), the 'private' sphere has received considerably less attention (cf. Fenster 2005). In exploring livein care as reproductive work that takes place in the private home but impacts on the workers' participation in everyday life in the city, we simultaneously draw on and move beyond the private and public spheres as conceptual tools and construct a framework that disrupts the public/private dichotomy.

Looking at the case of care workers who reside in Basel regularly but only for short periods of time, we critically investigate both the formal mechanisms and state-directed rights-based frameworks, as well as the concept of inhabitance in the case of repeated mobility. This involves moving beyond a territorial conceptualization of the city to an 
understanding of space as a product of interrelations (Massey 2005). In this sense, citadins negotiate their right to the city through connections to other places. With our focus on circular migrants these interrelations become especially visible. Our aim is to contribute in this way to an understanding of urban participation and 'citizenship' that "makes it possible to think migration and city beyond [exclusionary] ethnicity paradigms" (Hess and Lebuhn 2014, 13) and beyond a territorial understanding of space.

\section{MATERIAL AND METHODS}

This paper is based on a three-year project funded by the Swiss National Science Foundation. In our project, we followed the network connections that make up the Swiss 24-hour care market, and identified key sites, actors, and moments that shape its development. Our findings are based on a diverse set of observations, qualitative interviews and informal conversations between 2013 and 2016. As part of our observation of the 24-hour care market, we analyzed the extensive public debate on live-in elderly care in the popular media and in government proceedings. Furthermore, we carried out a close reading of relevant documents and an analysis of care agencies' marketing and self-presentations on the Internet.

We conducted in-depth interviews with twelve care workers from Hungary, Slovakia and Poland, twenty representatives of thirteen different care agencies, and two representatives of workers' organizations in Switzerland. Five interviews were carried out in Slovakian, six in Hungarian and all the others in German. The non-German interviews were translated into English by our field assistants. With a few exceptions, the interviews were transcribed verbatim. Except for one respondent aged 29, the care workers we interviewed were aged 45 to 67 years old, were all female and had diverse educational and family backgrounds. We use pseudonyms for all interviewees and persons mentioned in the quotations, except for Bożena Domańska and Agata Jaworska, who cannot be anonymized because they are well-known public figures in Switzerland and who gave us their explicit consent to publish their names, photos and the quotations printed below.

Moreover, we draw on our notes from many informal conversations with care workers, agency and union representatives and other individuals such as government officials. During the course of our research, we visited the care workers' grassroots group Respect; we followed some of their network connections to worker recruitment sites in Slovakia and Hungary and visited care workers at their workplaces and at their homes in Switzerland and Hungary. For the analysis, we drew on Waitt's (2010) suggestions about how to analyze material from a discourse analytical perspective. 


\section{RESULTS AND DISCUSSION}

In the following three sections we discuss how the Swiss migration, work and gender regime affect the circular migrant care workers' right to the city and how they negotiate their everyday lives as inhabitants individually and collectively.

\subsection{Free movement of workers and circular migration}

The admission of migrant workers to Switzerland is based on a dual system that grants (gainfully employed) nationals of European Union (EU) or European Free Trade Association (EFTA) member states the right to free movement, while only giving work permit to a limited number of highly skilled employees from non-member states. The dual system is based on the idea that low-skilled labor can be filled by workers from within the European Union, especially from the newer accession states in Eastern Europe (Castles 2006). These regulations concerning the free movement of persons to Switzerland form the basis of the current model of live-in home care work. While live-in carers from non-member states can still only work informally, the regulations now enable care workers from EU/EFTA to legally enter Switzerland and find formal employment. Since Switzerland extended the freedom of movement to eight new Eastern European member states in 2011, the number of agencies that offer packaged live-in care services has markedly increased. The agencies recruit carers from countries such as Poland, Slovakia, and Hungary, most of whom work in Switzerland for only a few weeks or months at a time.

Temporary migration within the EU is not new. Many patterns of short-term and seasonal migration have prevailed in different forms (Castles 2006). Researchers and policy makers often subsume them under the term circular migration. The term describes a specific pattern of migration that is both temporary and repetitive (Triandafiyllidou 2010). It is commonly found with workers who go abroad for an assignment of a few weeks or months, then return home for some time before going back for the next assignment - sometimes even at regular intervals.

A number of scholars have noted that circular migration is increasingly promoted as a (top-down) policy (Triandafyllidou 2010; Vertovec 2007; Wickramasekara 2011) to foster development in home countries, to meet labor market needs without permanent settlement, and to minimize irregular migration to the receiving countries. In short, circular migration is claimed to generate so-called triple-win situations (Castles and Miller 2009; Wickramasekara 
2011). The European Commission and the Global Forum on Migration and Development for example strongly promote the idea of actively managed circular migration (European Migration Network 2011; GCIM 2005). Private home care agencies adopt this win-win-win logic, too. Their model of sending care workers back and forth between country of permanent residence and workplace in Switzerland every two to twelve weeks epitomizes short-term circular migration.

As Marchetti (2015) points out, circular migration is special in that it requires specific skills to deal with the required geographical mobility. In addition to organizing repeated cross-border transfers, many circular migrants in domestic work are also responsible for recruiting and managing their replacement workers, arranging schedules, handing over tasks and keeping in touch with employers from a distance. Therefore, researchers call for a bottom-up approach to circular migration that pays attention to the migrants' reality on the ground (Triandafyllidou and Marchetti 2013).

Furthermore, circular migration has strongly gendered characteristics (Triandafyllidou and Marchetti 2013). In contrast to longer stays abroad, circular migration helps workers to secure a livelihood without emigrating permanently. Going back and forth at brief intervals allows them to spend time with their family in between assignments. For this reason, it is often women who seek such job opportunities, as they allow for earning money abroad while continuing to fulfill typically gendered care responsibilities in their home country (Marchetti 2013).

However, Wickramasekara (2011) argues that such circular migration programs lead to numerous protection problems and rights issues that apply especially to low-skilled workers. The next section shows how the interplay between the migration and work regimes in Switzerland results in different degrees of social and political exclusion for live-in migrant care workers and hence affects their right to the city, with regard to the four aspects of rights, access, belonging, and participation.

\subsection{The situation of live-in care workers in Switzerland: influenced by intertwined migration, work and gender regimes}

Although paid home-care work is increasingly common, public perception and politics often neglect home care as an employment field. Feminist research has shown that this disregard is typical for so-called reproductive work, which is performed in the private space of the home and has long been done by unpaid female family members (for an overview see Kofman and 
Raghuram 2015). Consequently, labor law in many countries, including Switzerland, does not protect paid care work in the private household. Furthermore, live-in care workers are often not represented by labour unions (ILO 2013). This exclusion means that working time, occupational health and safety, and workplace monitoring are regulated less strictly than in other sectors of the labor market (Medici 2011).

Additionally, the care workers' rights highly depend on the length of their residence and the formality of their work arrangements. Since the Free Movement of Persons Act between Switzerland and the EU/EFTA came into force in 2002, care workers from EU and EFTA states have been able to obtain mainly three different types of residence permit (State Secretariat for Migration 2015b). While employees with unlimited working contracts can apply for residence permits that are valid for five years, workers with an employment contract valid from three to twelve months can only apply for short-term permits. The validity of these short-term permits is identical to the term of the employment contracts and can be extended for a maximum of one year. Workers who stay in Switzerland for less than three months a year cannot apply for residency and are only registered with the local authorities via an online form (State Secretariat for Migration 2015a).

For migrant live-in care workers, the Free Movement of Persons Act means that they can now legally enter and work in Switzerland. However, our data suggests that they still often work informally, especially those who work in Switzerland for less than three months a year. We found that many of them are not fully registered with the authorities for such benefits as social insurance and pension schemes. Sara, a young woman from Slovakia, recalled her experience with a recent deployment as live-in care worker:

"He (the care recipient) didn't know anything. You know, I wasn't even registered with the communal authority. I asked him about it, and about taxes, health insurance, you know, normal things. It is not the first time I am in Switzerland. (...) I have worked in Switzerland before and everything was legal and correct then. And now, moonlighting! One or two months and then I went home. (...) I didn't know that and I wouldn't even have come [had I known]." (Sara, care worker)

While many workers remain unregistered, others have to work on short-term contracts. This not only limits their right to stay in Switzerland but also produces insecure job situations. Leila, for example, was a care worker in informal employment arrangements in Switzerland and Germany for many years. When we talked to her, she was working for a family in Basel her first formal employment abroad. However, Leila's current employer had decided to renew her employment contract for only half a year at a time, which led to her residence permit 
being also only renewed for half a year every time. For her, this caused considerable confusion and stress:

I don't understand either. The elderly person I take care of is 84 years old. Slightly dement, but in good shape. He is not about to die in two days. Nor in half a year. (...) Well, [this is] not good. No, it makes me anxious. And you know, in such a case I often think that because I'm very frustrated, it would be better in informal [economy]. At least I wouldn't have such problems. (Leila, care worker)

Hence, for Leila, working on a series of formal short-term contracts was even more frustrating than being in informal employment, in which she would at least not have to worry about the corresponding administrative work.

In many respects, carers with residence permits are better off than employees with short-term permits or without permits. If a carer with a residence permit loses her job, $\mathrm{s} / \mathrm{he}$ has the right to stay in Switzerland, has access to unemployment benefits, and can apply for social assistance (SKOS 2011). For short-term workers whose permits expire with their employment contracts, however, it is far more difficult to claim assistance. Although they pay the same share of unemployment benefits through automatic deduction from their salaries and would de-jure be eligible for unemployment benefits, we found that they cannot access these benefits due to their missing residence permits. In this sense, the intertwining of migration and work regimes complicates live-in care workers' rights and access to resources.

Moreover, our research suggests that the work arrangement of live-in care itself is specifically tailored to circular migrants. As the following quote by an interviewed care agent illustrates, live-in care workers are clearly not meant to stay longer and form ties in the city in which they work:

This [the idea that a live-in care worker would aspire to social mobility and to build an autonomous life] is not our goal. (...) Imagine: a woman comes here as a live-in care worker, starts to save money, and starts to pay rent for her own apartment. And then her boyfriend joins her (...), they live together. Maybe they have two kids then. Now, (...) is this women supposed to sleep, to live with the care-recipient? Forget it! (...) This model is not suitable for residents. (... ) As soon as they are permanently here and they live here, they are never going to accept a job like that. (Bruno, care agent)

This quotation shows that live-in care work is not easily reconcilable with having one's family in spatial proximity. Even if some might wish to, live-in carers are not supposed to conceive of the center of their lives being in Switzerland but in their 'home' countries. Correspondingly, their wages are usually not sufficient to secure a decent livelihood in Switzerland, let alone to bring family members from their countries of origin to their work country. 
Nevertheless, the temporary deployments might help them improve their livelihoods and take care of family members in their cities of permanent residence. Indeed - in agreement with the findings of Marchetti (2013) - results of our interviews with several women who cared for family members at home showed that the short-term circular mobility of their jobs was a desirable condition. Dania, a care worker from Poland, for example, told us that her employer wanted her to stay and work permanently, but she preferred to share the live-in care arrangement with a colleague so that she could go home between her month-long shifts.

But several of our interviewees also pointed out that their intermittent absences from home and constant back-and-forthing between two places take their toll. Melissa, for example, had done three one-month deployments as a live-in care worker from Hungary to Switzerland and was planning to go on more deployments the following year. Asked about how she handled going back and forth repeatedly, she said::

It's bad for everyone. Everyone. The drivers even say, anybody you talk to, no matter where they go to work, Germany, Austria, or anywhere, that when leaving, everybody is silent, sad, and on the way home, we almost sing. Yes. You're away from your home for a month. (Melissa, care worker)

This quote hints at the difficulties of traveling long distances across national borders between 'work' and 'home' at a monthly rhythm. Short-term circular migration changes the social networks of live-in carers and their practices to maintain existing social relations. Many of our interview partners, both care workers and care agents, emphasized the importance of access to resources such as affordable means of communication, transportation, space to socialize and to meet people, without which existing relations could not be maintained and new ones between two or more places separated by thousands of miles - and in our case also across national boundaries - could not be built.

In principle, according to Levitt and Schiller (2004) a 'transnational life' implies the possibility of developing feelings of belonging in various locations. However, in the case of live-in carers, the working and living conditions of live-in arrangements make it difficult for them to meet other people and to participate in social life outside their workplaces. These difficulties are especially visible in Magdalena's case. Magdalena was working in two households in Switzerland, staying one month at each while occasionally spending a couple of days at home in Hungary in between. The following fieldnotes are from our second visit at her workplace:

Ms. Meyer (care-recipient) has been very agitated and keeps yelling at night. (...)

Magdalena is very worried that Ms. Meyer's shouting disturbs the neighbors (...). 
Normally, Magdalena likes to go for a walk or to leave the house for a little while. But right now she prefers to stay home during her free time from $2 \mathrm{pm}$ until 4pm, in case Ms. Meyer yells again or in case something happens. (Fieldnotes after a visit to Magdalena's and Ms. Meyer's)

As the persons they look after often require around-the-clock care, carers have little 'leisure time'. Although their working contracts usually stipulate maximum working hours of six to eight hours a day, our interviewees report that these hours are spread throughout the day and evening. Furthermore, they often work more than the hours written in their contracts and remain on call for the remaining hours. Consequently, many of them hardly ever feel properly off work, as Anna, a live-in care worker from Hungary who had been working for two years in Switzerland, confirms:

It was not a problem for me to wake up at night. I knew, it's 24-hour work, just like having a little child, one has to be awake. (...) I rested whenever I was able to. (...) I woke up, even if they didn't ring - but I heard (them), because our rooms were separated only by a hallway and a bathroom. (...) Actually, for this job, I think this kind of alertness is necessary. (...) those who don't fall asleep and wake up easily, they suffer greatly because they cannot get a rest. (Anna, care worker)

In this quotation, Anna is well aware of the required 'work ethic' and behavior that is considered necessary for 'good care' (Weicht 2010).. In comparing it with having a little child she frames care work as mothering - a gendered responsibility that requires around-the-clock presence. Furthermore, the comparison to mothering emphasizes that care work encompasses affective, embodied work. Care work, which includes providing intimate services and a loving environment, often produces relationships based on love and affection (McDowell 2009). These emotional ties make it even more difficult for carers to claim time off work while feeling responsible for the care recipient.

To sum up, this section identified a number of difficulties faced by circular labor migrants who work in live-in care arrangements. These difficulties stem from the specific intersection of migration regime, work regime and gender regime, and how this affects the workers' right to the city. We argue that it is this intertwining of a short-term circular migration system and a live-in work arrangement in the private household that relies on gendered understandings of care work, which structurally complicates enjoyment of 
- equal rights for live-in home care workers with regard to residence permits and labor law,

- equal access to unemployment benefits, social assistance, and other resources,

- the possibility of leaving the workplace/household for a longer period of time and claim time off work to live one's own life, for example to meet compatriots, build new social networks, and develop a sense of belonging, and

- the acquisition of financial and other means to build an independent life in the city, for example to rent one's own apartment, go for a coffee, to the theatre and movies, and participate in other activities of one's own choice - similar to the resident urban population.

\subsection{Negotiating everyday life in the city and transforming the city collectively}

In the previous sections, we discussed how the specific nexus of the migration, work and gender regimes in Switzerland complicates live-in care workers' access to resources and their belonging and participation in the city. However, in spite of the above-mentioned disenfranchisements due to closely intertwined formal and informal mechanisms, live-in carers are local inhabitants who actively participate in the struggle for 'empowerment' (Schilliger 2015; Strüver 2013). This section first looks at examples of how care workers negotiate their participation in the everyday life in the city on an individual level. Then we will come back to Harvey's argument that the right to the city means more than just individual freedom and includes the right to form alliances and collectively transform the city (Harvey 2008).

Many of our interview partners underlined the absolute necessity of having access to an Internet connection in the elderly person's household. By means of smartphones, computers, and communication software such as Skype, care workers can reach their friends and family and be contacted anytime from anywhere in the world. Above all, social media platforms such as Facebook play an important role for their social life. During our visits, many of our interviewees would show us that they take pictures of their surroundings, of the city, of the landscape around the workplace, of themselves and the elderly and share them on social media platforms with their friends and family members. Vice versa they comment and look at posts and pictures from colleagues and family from other places and from 'back home'. Moreover, our interviewees told us stories of how they meet and interact with new acquaintances in the environment of their workplace. Magdalena, for example, vividly 
recalled her encounter with a girl at the bus station and how she appreciated exchanging phone numbers. She was also proud of showing us the photos of her visit at the opera with the care-recipient's daughter, which she had posted on Facebook. Through these and other practices care workers develop a sense of belonging in different places. Also, live-in carers often participate in specific Facebook groups in which they exchange information about employment opportunities or to support each other in care work related subjects. These new forms of communication and relations via the Internet enable the care workers to participate in the local everyday life at their workplaces while continuing to 'inhabit' their cities of permanent residence - even though they are intermittently physically absent (Longhurst 2013). In this respect, they are citadins in two places at once.

Live-in care workers not only appropriate the city by developing social relations and through feelings of belonging, they also fight for better working conditions. In Basel for example, we met Bożena Domańska, who sought the support of a labor union and filed a lawsuit against her former employer. In 2013, she was portrayed in a Swiss national television documentary (Batthyany 2013). As a result of the film, which was key to bringing labor conditions of live-in care workers to public attention, Bożena Domańska lost her job as a livein care worker. Later, she was able to find new employment as a live-out carer. She settled permanently in Basel and became the public face, social organizer and spokesperson of live-in care workers. In this process she gained access to resources, belonging, and participation in the city, none of which are within easy reach for most temporary migrants, let alone for shortterm circular migrants. In the following quote she recalls the importance of her fight and the need for collective organization:

If I hadn't told anyone back then (...), if I hadn't started this lawsuit or if I hadn't defended myself, it would have been over. And I said: No, stop. Then they approved my claims. You have to take matters into your own hands and say 'here I am' and 'not like that'! (...) we are all individuals, but together we can achieve more. (Interview with Bożena Domańska, care worker) ${ }^{2}$

\footnotetext{
${ }^{2}$ This interview was conducted by one of our students, Severin Luca Belle, as part of a seminar on ,care arrangements - aging and care in private households' at the University of Zurich in 2014.
} 


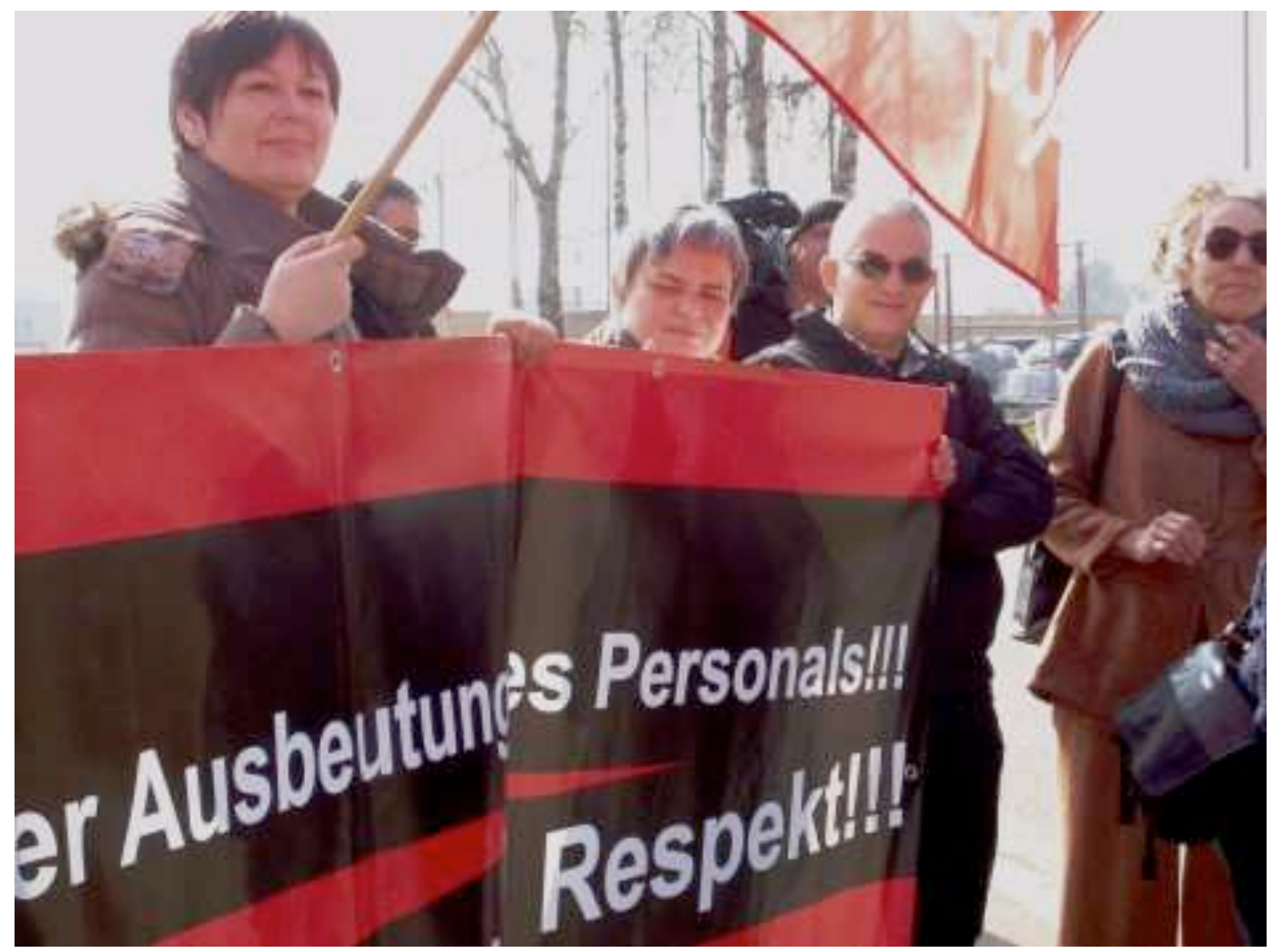

Photo: Bożena Domańska (left) at a street protest against the exploitation of care workers. Photo with kind permission of: Respect@VPOD

Traditionally, organizing workers employed in private households was not a priority for labor unions. These workers were perceived as servants who are part of the family rather than as laborers, and with most of them being women, they did not rank high on the agendas of the male-dominated unions. Furthermore, unions often argued that care workers' isolation in individual households made them impossible to organize (Boris and Fish 2014).

However, recent years have witnessed an upsurge of care workers organizing in large parts of the world. These movements have been initiated and supported not only by unions, but also by women's associations, migrant or religious organizations, human rights advocacy groups and other non-governmental organizations (Ally 2005). In contrast to unions the latter do not necessarily focus on labor conditions, but often also address questions of gender and ethnic discrimination or citizenship (cf. e.g. Ong 2006; Pratt 2012). When the International Labor Organization (ILO) put care workers on their agenda in 2008, many of these unions and associations allied at a global level to campaign for the adoption of the ILO convention 189 
(Boris and Fish 2014; Schwenken 2017). The convention passed in 2011, requiring states to grant equal labor rights to domestic workers (ILO 2011).

While the existing literature on care workers' labor activism takes into account that they are predominantly migrants with no or only temporary residence permits (cf. Ally 2005), the cases discussed usually deal with workers who are present for longer periods of time. In our case of circular migration, however, most care workers stay in Switzerland only for a few weeks at a time. This additionally complicates the building of longer-term alliances and workers' organizing in a way that might support collective change in the city. Moreover, they work in live-in arrangements in which the required around-the-clock presence makes it difficult for the workers to find time for such activities and meet other workers (Schilliger 2015).

In spite of these added difficulties, a group of live-in care workers around Bożena Domańska managed to successfully organize. In spring 2013 they founded an alliance called Respect (Respekt 2015). Its initial members were mainly live-in care workers from Poland who went to a Polish-language church service in Basel on Sundays. Afterwards, they would meet for coffee and tea and discuss their work situations. The women got in touch with a researcher and representatives of the labor union for the public services personnel (VPOD). Together, they set up more formal monthly meetings on Sunday afternoons. The group's main aim was to support each other and to exchange information. Today they continue to discuss individual work situations and how to best deal with them. They support each other in finding jobs and collect knowledge about their labor rights. Over time, the group has broadened beyond the Polish community and now includes women from Slovakia, Hungary, and other countries. While Bożena Domańska is now a permanent resident, many of the group members work in short-term circular arrangements. Exchange among group members is fostered by a blog and an online discussion forum, which enables them to keep in touch also from afar.

One key concern they shared from the beginning was that many of them worked longer hours than stipulated in their working contracts. With the support of other live-in care workers, researchers, and juridical experts of the labor union, care worker Agata Jaworska decided to bring her case to the civil court of Basel. She sued her former employer, a care agency, for all the hours she worked for or was on call in her client's household without being paid. 


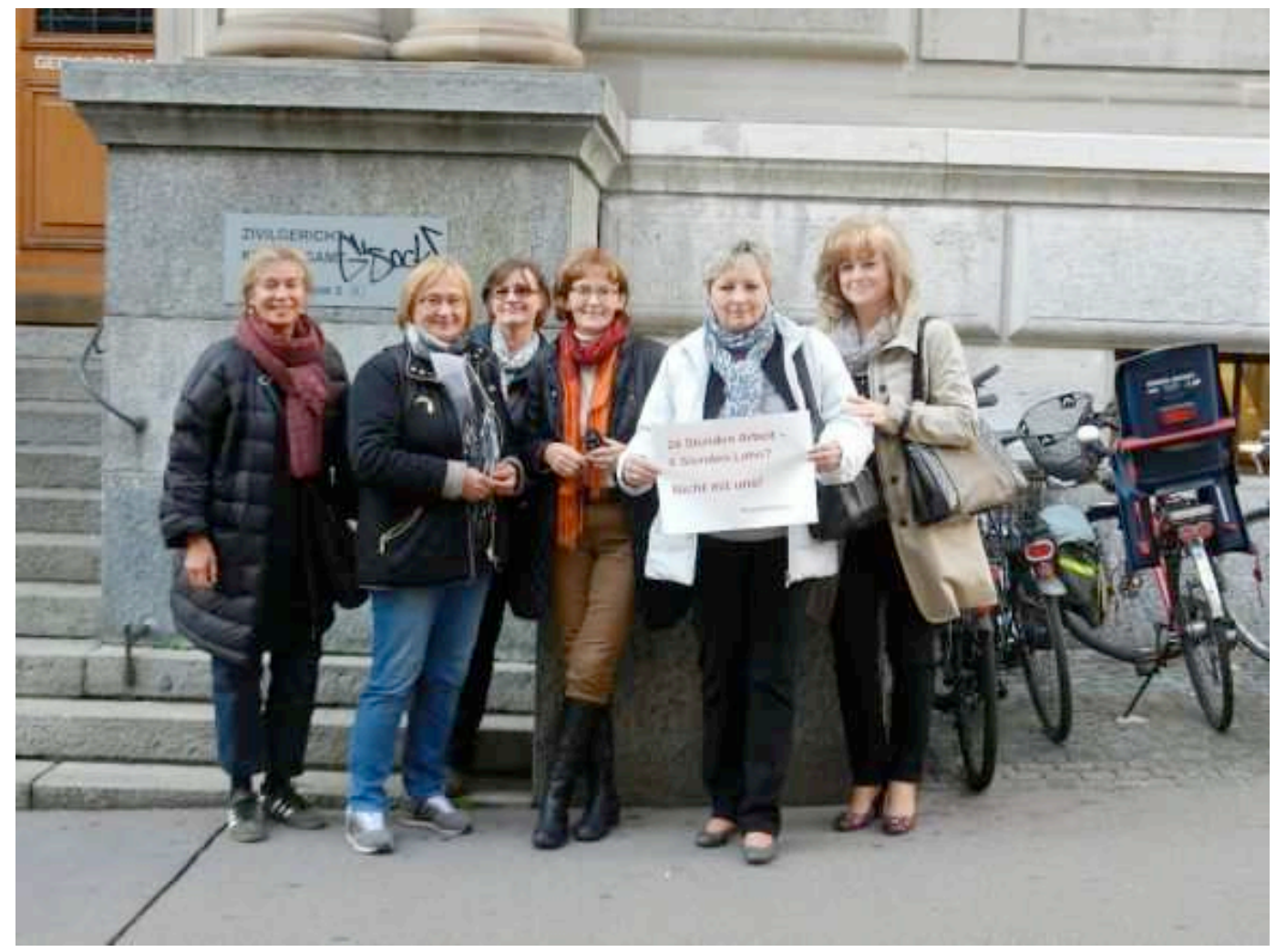

Photo: Agata Jaworska with some of her colleagues from the group "Respect" when they deposited her claim at court. The sheet she holds reads (in German): "24 hours of work - six hours paid. Not with us!'Photo with kind permission of: Respect@VPOD

In Spring 2015 the Basel court ruled that Agata Jaworska was to be compensated in full for all additional hours she worked and that she should get half of her usual hourly wage for every hour spent on call in the household. The total compensation amounted to an additional 17,000 USD for three months of 24-hour care work (Schilliger 2015, 173).

The women of Respect celebrated the court ruling as a landslide victory for live-in care workers in Basel. While it might not change their often disadvantageous situation with regard to migration and labor rights at the national level, it was a victory that the cantonal judiciary of Basel acknowledged their claim to be compensated for all hours at work and on call. In the months since this ruling, Respect has encouraged and helped other members of the group to file similar claims, taking Agata Jaworska's case as precedent (for a more detailed account of the development and activities of Respect see Schilliger 2015).

As a consequence, employers of live-in care workers have become increasingly aware that their employees might have to be compensated for any additional hour they worked for or 
were on call in a household. Even though it remains to be seen whether courts in other cities will rule cases similarly, on the level of the city of Basel, this mandate challenges the previously widely-used and largely undisputed practice of paying live-in care workers only for a fraction of the hours they work in households of elderly people. Hence, the urban scale served as arena for changing existing regulations 'bottom up' and it holds the potential to initiate changes in other cities. In September 2015 Respect received the equal opportunity prize awarded by the city of Basel. It is currently trying to found branches in other major cities in Switzerland.

The case study of Respect demonstrates how a small alliance of workers, unionists, and researchers succeeded in changing the rules of how live-in care work is remunerated in Basel. In addition to their success in the court case, the group has become a community and network for care workers, which facilitates their sense of belonging in the city. By using Facebook and other Internet based communication, the network enables participation even during the months the workers are not living in Basel. In this sense again, the care workers remain 'inhabitants' of the city even during their intermittent absences.

\section{CONCLUSION}

Following our analysis, we would argue that adding a gender lens to the right-to-the-city framework includes three aspects. First, it broadens our scope of interest from questions of formal citizenship and political participation to the everyday life of the city's inhabitants. Second, it shifts our attention from the more visible, 'public' spheres of the city to what often remains invisible because it is deemed 'private' - including care work in private households. And third, a gender lens foregrounds that the right to the city is more than the freedom of an ostensibly autonomous individual. It focuses on the collective level and allows us to ask in what ways a given city's inhabitants form alliances and collectively strive for transforming existing practices, rules, and regulations.

We explored this understanding of a 'gendered right to the city' in the case of live-in care workers in German speaking Switzerland, with a specific focus on the Swiss city of Basel. Our analysis shows that women's rights, access to resources, their belonging, and participation - both at the individual and collective levels - are directly related to the work arrangements in live-in care employment. Based on this, we think that the right-to-the-city debate should strengthen its focus on labor-related rights and issues. We would argue that 
working conditions are often key in shaping inhabitants' possibilities to negotiate their right to the city and that they should receive more attention in future debates.

Furthermore, our example of live-in care workers allows for exploring what negotiating one's right to the city might mean in the context of heightened mobility. As shortterm circular migrants, care workers inhabit the city only for a few weeks at a time. In spite of their intermittent absences, our research has shown how the care workers built social networks and developed feelings of belonging. We also noticed that to maintain these relations, they strongly rely on smartphones, computers and communication software such as Skype, which allows workers to participate in everyday life in more than one city at the same time. This example confirms the key role of modern communication technology in contexts of increased mobility and it shows the importance of adopting a relational understanding of space that transcends a territorial focus on a single city. Inhabitance might not be limited to only one city at a time and it is produced through interrelations to other places.

However, a situation of increased mobility complicates the adoption of longer-lasting commitments and labor activism. It exacerbates some of the challenges of organizing care workers documented in the existing literature (cf. Ally 2005). As the example of Respect shows it is possible to successfully organize, even for circular migrants. In our case, this activism was fostered by collaboration with local researchers and union activists. We argue that modern communication tools and alliances with local activists enable circular migrants to participate in the transformation of existing practices and hence in the restructuring of power relations that underlie everyday life in the city, even if they reside in the city only for short periods of time. By claiming their right to the city in this way, short-term dwellers contribute to (re)shaping the urban space so that it better meets their needs as - intermittent - inhabitants.

\section{ACKNOWLEDGEMENTS}

We are deeply grateful to Bożena Domańska and Agata Jaworska for sharing their stories. Additionally, we would like to thank all our interviewees, the members of the care workers' network Respekt and the members of the working group on precarity in the think tank Denknetz for generously providing us insights into the practices and regulations of live-in care. Furthermore, we are indebted to Katalin Ráhel Turai for her invaluable assistance out in the field and to Severin-Luca Bellè for providing a very helpful interview. Finally, we would like to thank Elena Vacchelli, Eleonore Kofman, Anne Zimmermann and our colleagues of 
the economic geography research group at the University of Zürich for their valuable comments on earlier versions of this article.

\section{Bibliography}

Ally, S. (2005) Caring about Care Workers: Organizing in the Female Shadow of Globalization. Labour, Capital, and Society, 38, 185-207.

Bakan, A. B. \& D. K. Stasiulis (2012) The Political Economy of Migrant Live-in Caregivers: A Case of Unfree Labour? In: Legislated inequality. Temporary labour migration in Canada. eds. R. Patti \& C. Straehle, 202-226. Montreal: McGill-Queen's University Press.

Batthyany, B. (2013) „Hilfe aus dem Osten“ - Pflegemigrantinnen in der Schweiz ("Help from the East" - Women care migrants in Switzerland). Documentary of the Swiss National Radio and Television.

Boris, E. and Fish, J. N. (2014) 'Slaves No More': Making Global Labor Standards for Domestic Workers. Feminist Studies, 40, 441-443.

Brown, W. (2000) Suffering rights as paradoxes. Constellations, 7, 208-229.

Butler, C. (2012) Henri Lefebvre: spatial politics, everyday life and the right to the city. Abingdon: Routledge.

Castles, S. (2006) Back to the future? Can Europe meet its labour needs through temporary migration? International Migration Review, 40, 741-766.

Castles, S. \& M. Miller (2009) The Age of Migration. Basingstoke: Palgrave Macmillan.

Domosh, M. \& J. Seager (2001) Putting women in place: Feminist geographers make sense of the world. New York: Guildford Press.

European Migration Network (2011) Temporary and circular migration: empirical evidence, current policy practice and future options in EU member states. Luxembourg: European Union.

Fenster, T. (2005) The right to the gendered city: Different formations of belonging in everyday Life. Journal of Gender Studies, 14, 217-231.

Fenton, A., R. Lupton, R. Arrundale \& R. Tunstall (2013) Public housing, commodification, and rights to the city: The US and England compared. Cities, 35, 373-378.

Forum, W. S. (2004) World Charter for the Right to the City. Quito: World Social Forum.

Fudge J. (2011) Global care chains, employment agencies and the conundrum of jurisdiction: decent work for domestic workers in Canada. Canadian Journal of Women and The Law, 23, 235-264. 
GCIM Global Commission on International Migration (2005) Migration in an interconnected world: New directions for action. Geneva: Global Commission on International Migration.

Hackenbroch, K. (2013) The spatiality of livelihoods - negotiations of access to public space in Dhaka, Bangladesh. Stuttgart: Franz Steiner.

Harvey, D. (2008) The Right to the City. New Left Review, 53, 23-40.

--- (2012) Rebel cities: from the right to the city to the urban revolution. London: Verso.

Hess, S. \& H. Lebuhn (2014) Politiken der Bürgerschaft. Zur Forschungsdebatte um Migration, Stadt und Citizenship (Politics of citizenship: On the debate on migration, city and citizenship). sub|urban. zeitschrift für kritische stadtforschung, 2, 24.

ILO International Labour Organization (2011) Convention 189. Decent work for domestic workers. Geneva: ILO.

ILO International Labour Organization (2013) Domestic Workers Across the World: Global and regional statistics and the extent of legal protection. Geneva: ILO.

Jabareen, Y. (2014) 'The right to the city' revisited: Assessing urban rights - The case of Arab Cities in Israel. Habitat International, 41, 135-141.

Joy, M. \& R. K. Vogel (2015) Toronto's governance crisis: A global city under pressure. Cities, 49, 35-52.

Kofman, E. \& E. Lebas (1996) Lost in transposition: Time, space, and the city. In Writings on Cities. Henri Lefebvre, eds. E. Kofman \& E. Lebas, 3-60. Cambridge: Blackwell.

Kofman, E. \& P. Raghuram (2015) Gendered migrations and global social reproduction. London: Palgrave Macmillan.

Lefebvre, H. (1968) Le droit à la ville. Paris: Editions anthropos.

--- (1991) The production of space. Oxford: Blackwell.

--- (1992) Eléments de rythmanalyse: introduction à la connaissance des rythmes. Editions Syllepse.

--- (1996) The right to the city. In Writings on Cities. Henri Lefebvre, eds. E. Kofman \& E. Lebas, 147-159. Cambridge: Blackwell.

Levitt, P. \& N. G. Schiller (2004) Conceptualizing simultaneity: A transnational social field perspective on society. International Migration Review, 38, 1002-1039.

Longhurst, R. (2013) Using Skype to mother: bodies, emotions, visuality, and screens. Environment and Planning D: Society and Space, 31, 664-679.

Mansoor, A. \& B. Quillin (2007) Migration and remittances: Eastern Europe and the former Soviet Union. Washington DC: World Bank.

Marchetti, S. (2013) Dreaming circularity? Eastern European women and job sharing in paid home care. Journal of Immigrant and Refugee Studies, 11, 347-363. 
Marchetti S. (2015) Employability, gender and migration. The case of Eastern European circular carers in Italy. Swiss Journal of Social Work, 17, 71-84.

Marcus, G. M. (1995) Ethnography in/of the world system: The emergence of multi-sited ethnography. Annual Review of Anthropology, 24, 95-117.

Massey, D. (2005) For Space. London: Sage.

McDowell, L. (2009) Working bodies: interactive service employment and workplace identities. Malden, MA: Wiley-Blackwell.

Medici, G. (2011) Hauswirtschaft und Betreuung im Privathaushalt. Rechtliche Rahmenbedingungen (Domestic work and care in the home. Legal framework). Juristisches Dossier im Auftrag der Fachstelle für Gleichstellung der Stadt Zürich, der Gewerkschaft VPOD und der Gewerkschaft Unia.

Mullis, D. (2014) Recht auf die Stadt (Right to the city). Münster: Unrast.

Nagel, C. \& L. Staeheli (2004) Citizenship, migration and transnational migration: Arab immigrants to the United States. Space and Polity, 8, 3-23.

Ong, A. (2006) Mutations in Citizenship. Theory, Culture \& Society, 23, 499-531.

Pelzelmayer, K. \& K. Schwiter (2015) Working but not living here. (Im)mobilisation of circularly migrating workers. Paper presented at the German Kongress of Geography. Humboldt University, Berlin.

Piper, N. (2010) Temporary Economic Migration and Rights Activism: An Organizational Perspective. Ethnic and Racial Studies, 33, 108-125.

Plewa, P. \& M. J. Miller (2005) Postwar and Post-Cold War Generations of European Temporary Foreign Worker Policies: Implications from Spain. Migraciones Internacionales, 3, 58-83.

Pratt, G. (2012) Families apart: Migrating mothers and the conflicts of labor and love. Minneapolis and London: University of Minnesota Press.

Purcell, M. (2002) Excavating Lefebvre: The right to the city and its urban politics of the inhabitant. GeoJournal, 58, 99-108.

--- (2003) Citizenship and the right to the global city: reimagining the capitalist world order. nternational Journal of Urban and Regional Research, 27, 564-590.

Respekt (2015) Das VPOD-Netzwerk-Respekt für BetreuerInnen in Privathaushalten (The VPOD-network Respect for carers in private households). http://respekt-vpod.ch/ (accessed 25.01.2016).

Ruhs, M. \& P. Martin (2008) Numbers vs. Rights: Trade-Offs and Guest Worker Programs. International Migration Review, 42, 249-265.

Sassen, S. (2001) The global city: New York, London, Tokyo. Princeton and Oxford: Princeton University Press. 
Schilliger, S. (2013) Transnationale Care-Arbeit: Osteuropäische Pendelmigrantinnen in Privathaushalten von Pflegebedürftigen (Transnational care-work: Eastern European circular migrants in the private households of care recipients). In Who Cares? Pflege und Solidarität in der alternden Gesellschaft, ed. Schweizerisches Rotes Kreuz, 142161. Zürich: Seismo Verlag.

--- (2014) Pflegen ohne Grenzen? Polnische Pendelmigrantinnen in der 24h-Betreuung: Eine Ethnographie des Privathaushalts als globalisiertem Arbeitsplatz (Caring without borders? Polish circular migrants in 24h care: An ethnography of the private household as a globalised workplace). Dissertation at the University of Basel, Switzerland.

--- (2015) "Wir sind doch keine Sklavinnen" (Selbst-)Organisierung von polnischen CareArbeiterinnen in der Schweiz ("We are no slaves" (Self-)organising of Polish care workers in Switzerland). In Zerstörung und Transformation des Gemeinwesens, ed. Denknetz, 164-177. Zürich: Edition 8.

Schwiter, K., C. Berndt \& J. Truong (2015) Neoliberal austerity and the marketization of elderly care. Social and Cultural Geography, Online first.

SKOS Swiss Association of Welfare Organisations (2011) Sozialhilfe und Personenfreizügigkeitsabkommen. Bewilligungsübersicht EU/EFTA-Bürgerinnen (Social welfare benefits and the free movement of persons act: Overview of permits for EU/EFTA-nationals). Bern: SKOS.

Staeheli, L. \& L. Dowler (2002) Social transformation, citizenship, and the right to the city: Introduction to the special issue. GeoJournal, 58, 73-75.

State Secretariat for Migration (2015a) EU/EFTA nationals. The various residence permits for nationals of EU and EFTA member states.

https://www.sem.admin.ch/sem/de/home/themen/aufenthalt/eu_efta.html (accessed 26 January 2016).

--- (2015b) Free Movement of Persons. Switzerland - EU/EFTA. https://www.sem.admin.ch/sem/en/home/themen/fza_schweiz-eu-efta.html (accessed 26 January 2016).

Strüver, A. (2013) "Ich war lange illegal hier, aber jetzt hat mich die Grenze übertreten" Subjektivierungsprozesse transnational moblier Haushaltshilfen ("I was here illegally for a long time, but now the border crossed me" - Processes of subjectivation of transnationally mobile domestic workers). Geographica Helvetica, 68, 191-200.

Tayebi, A. (2013) Planning activism: Using social media to claim marginalized citizens' right to the city. Cities, 32, 88-93.

Triandafyllidou, A. (2010) Towards a better understanding of circular migration. Working Paper of the European University Institute, Italy.

Triandafyllidou, A. \& S. Marchetti. (2013) Migrant Domestic and Care Workers in Europe: New Patterns of Circulation? Journal of Immigrant \& Refugee Studies, 11, 339-346.

Vertovec, S. (2007) Circular migration: the way forward in global policy? Working Paper of the International Migration Institute. Oxford: University of Oxford. 
Waitt, G. (2010) Doing Foucauldian discourse analysis: Revealing social realities. In Qualitative research methods in human geography, ed. I. Hay, 217-240. Oxford and New York: Oxford University Press.

Weicht, B. (2010) Embodying the ideal carer: the Austrian discourse on migrant carers. International Journal of Ageing and Later Life, 5, 17-52.

Wickramasekara, P. (2008) Globalisation, International Labour Migration and the Rights of Migrant Workers. Third World Quarterly, 29, 1247-1264.

Wickramasekara, P. (2011) Circular migration: a triple win or a dead end? Global Union Research Network Discussion Paper No. 15. 